\title{
The Construction of a Long-term Mechanism for the Return of Housing Prices to Rationality
}

\author{
Jianwu He \\ Xijing University, Xi'an 710123, Shaanxi Province, China
}

Keywords: housing prices rise; cause analysis; long-term mechanism

Abstract: At present, the market price of China's real estate market is too high and the growth rate is too fast, which has brought various new contradictions to the society. The central government has resolutely curbed the rise in housing prices. This paper introduces the current situation of China's real estate market price, analyzes the hazards and causes of excessive housing price rise, and proposes a method to promote the return of rational price of real estate market, in order to achieve a healthy and sustainable operation of China's real estate market and ensure the steady development of the national economy.

\section{Introduction}

The real estate industry has been in the important position of China's national economy for 20 years, but the irrational rise in house prices in recent years has affected the hearts of all parties in society. From "to curb the rapid rise in housing prices in hot cities" to "to insist that the house is used for living, not for speculation", and in July 2018, the Politburo meeting pointed out "resolutely curb housing prices".The high-level attitude firmly exposes the grim of the crisis. The root cause is that China's real estate industry lacks a stable and healthy long-term development mechanism ${ }^{[1]}$.

\section{The current situation of China's real estate market price}

Table 1: 2017 China's housing price rankings

\begin{tabular}{|c|c|c|}
\hline Ranking & Area & Average house price \\
\hline 1 & Beijing & $53087 \mathrm{yuan} / \mathrm{m}^{3}$ \\
\hline 2 & Shanghai & $47549 y u a n / \mathrm{m}^{3}$ \\
\hline 3 & Shenzhen & $43332 \mathrm{yuan} / \mathrm{m}^{3}$ \\
\hline 4 & Xiamen & $37818 \mathrm{yuan} / \mathrm{m}^{3}$ \\
\hline 5 & Nanjing & $23989 y u a n / \mathrm{m}^{3}$ \\
\hline 6 & Tianjin & $22584 \mathrm{yuan} / \mathrm{m}^{3}$ \\
\hline 7 & Guangzhou & $22051 \mathrm{yuan} / \mathrm{m}^{3}$ \\
\hline 8 & Hangzhou & $21212 \mathrm{yuan} / \mathrm{m}^{3}$ \\
\hline 9 & Sanya & $20478 \mathrm{yuan} / \mathrm{m}^{3}$ \\
\hline 10 & Zhuhai & $20375 y u a n / \mathrm{m}^{3}$ \\
\hline
\end{tabular}

China's real estate has started to leapfrog development since the second housing reform. 
Especially since the beginning of this century, after real estate as the pillar industry of the national economy, the real estate market has been driven by the national land, finance, taxation and other policies, and the development of the real estate market has achieved rapid development. At the same time, along with the advancement of the urbanization process, the real estate market price is also driven by rigid demand and investment, and the annual growth rate is much higher than the average speed of economic growth. Excessive housing prices have caused extreme dissatisfaction in society. (See Table 1).

\section{The danger of rapid rise in housing prices}

The excessive rise in housing prices is not controlled, and two major crises will be brewed: one is the economic crisis brought about by the bursting of the bubble, and high housing prices are not conducive to the transformation of economic development. Nowadays, the real estate industry has become the economic lifeline of many cities. This excessive dependence on the development model of the real estate industry will seriously jeopardize economic development in the long run. The other is the social fragmentation caused by the occurrence of negative assets, which inhibits the expansion of the middle class and seriously affects social equity. The soaring housing prices have widened the gap between the rich and the poor. Once the real estate enters the excessive speculation situation, the governance is very difficult, and the three problems of negative assets, financial bad debts and investment reduction will make the crisis intensify and the bubble will blow bigger ${ }^{[2]}$.

\section{Analysis of the causes of the rapid rise in housing prices}

\subsection{The real estate industry is overburdened}

In the past two decades, real estate has made remarkable contributions to the development of the national economy and the improvement of people's living standards. It can be seen that the economic growth rate is slow, stimulating real estate to drive the economy, local governments lacking money, and selling land to fill the gap. The development of the old city in the new district cannot be separated from the construction of housing. In these years, real estate has become the economic protagonist, and the responsibility is too heavy. And the imposed features make it overwhelmed, puffy and weak, and the nature of real estate is just a "ordinary" commodity, and it is urgent to return to healing.

\subsection{Inadequate industry governance system}

As a major necessities of people's lives, real estate lacks scientific development plans to guide the long-term healthy and orderly operation of the industry. The market model is single, focusing on high turnover, neglecting long-term rents, and renting and selling are not dual-track. In view of the housing demand at different income levels, there is a lack of systematic policies in terms of area, grade, taxation, subsidies, etc. to achieve hierarchical and multi-channel supply. There is a lack of market mechanism to optimize the allocation of social resources for the serious waste of multi-suites and vacant houses. Policy and market are often divergent, policies are not good, and short-sightedness is serious $^{[3]}$.

\subsection{Monetary policy directly impacts real estate}

According to the National Bureau of Statistics, broad money supply and house prices are in double-digit growth. The real estate industry has always acted as a reservoir for money, and for 
many years. The real estate has evolved into a high-hanging barrier lake. The central bank's second quarter report for 2018 shows that loan interest rates and quantities are still encouraging home buyers, and those profit-seeking financial departments are more willing to give money to real estate.

\subsection{People's real estate investment preferences are overheated}

The long-term farming economy has cultivated the people's deep real estate complex. It has become the pursuit of the Chinese people to save money and buy a house. It is a symbol of successful life. At the same time, the peripheral stock market is sluggish, the business is difficult, the equity investment income is unpredictable, and the residents' investment channels are not smooth. Buying a house has become the first choice for the rich and the rich, and has never been boosted by the insatiable enthusiasm of the people who have lost the investment in buying a house. The price of the house has soared. Figure 1 shows the situation of buying a house boom.

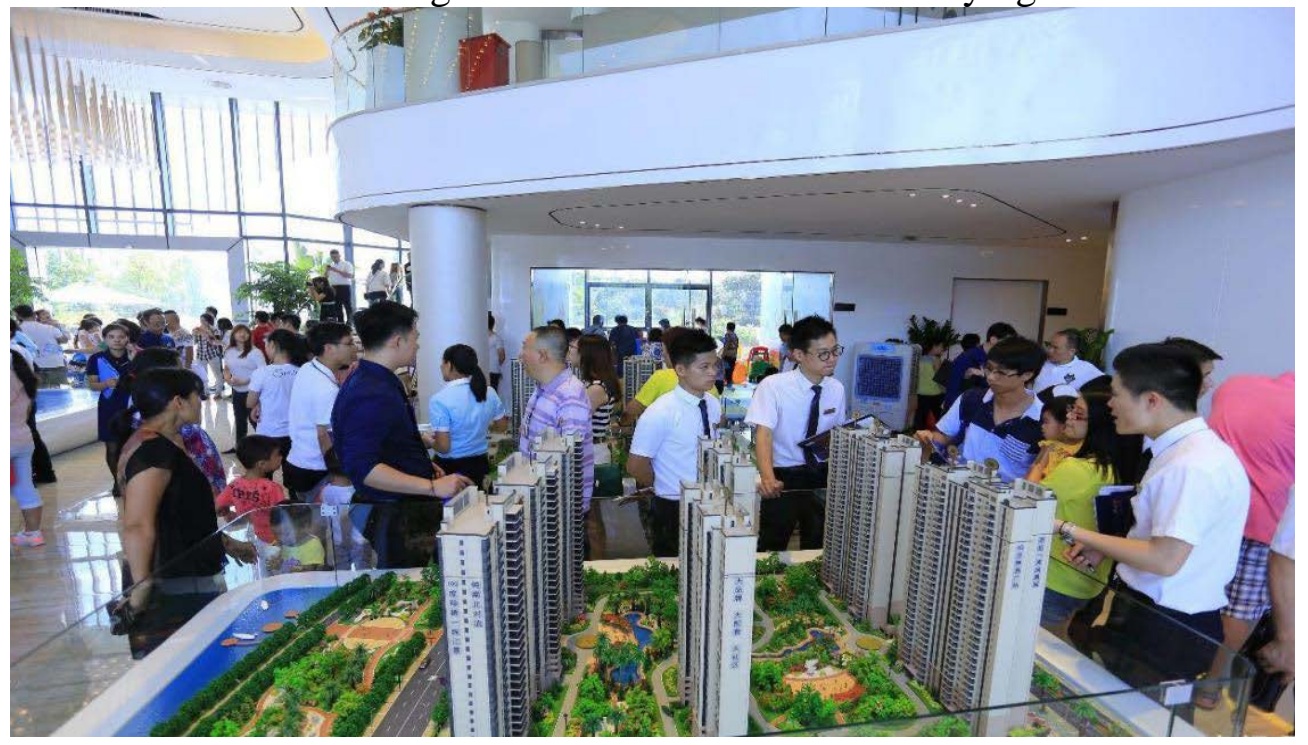

Figure 1: Large numbers of residents buy houses

\section{Constructing a long-term mechanism for the return of housing prices}

\subsection{Identify and implement the positioning of the real estate industry}

The real estate industry is an important industrial sector of the national economy. The industry should closely focus on the home ownership, the workers have their own places, and the development goals that meet the needs of the people's better life are constantly improving and developing, weakening their land finance, stimulating the economy, and absorbing excessive development. The excess function formed by currency for many years. The central and local governments should unify their thinking, recognize the situation, establish an industry orientation centered on the long-term healthy development of the industry, clarify their responsibilities, rationalize the fiscal and taxation system, break the original interest pattern, ensure the smooth flow of government, and work together to make the house return to residence attributes, build a long-term mechanism for industry development, and achieve sustainable development of the real estate industry ${ }^{[4]}$. 


\subsection{Improve the governance system of the real estate industry}

First, governments at all levels should comprehensively consider economic development, population growth, improvement of living standards, etc., and need to scientifically prepare regional real estate development plans, and provide scientific guidance to the market in terms of total volume, structure, quality grade, and technical direction. Second, all localities have rationally arranged land supply on an as-needed basis. In terms of supply and supply rhythm, the market is stable and the market is tempered. Third, the competent departments of the industry should strengthen the supervision of the housing construction process, increase the quality control of housing, review housing prices, and mobilize developers to adopt new technologies and new technologies to reduce costs and improve quality. Fourth, the government has invested heavily in building low-rent housing and affordable housing to do a good job. To achieve both rental and sales, multiple channels to ensure housing needs of residents of different income levels. Fifth, improve the relevant tax and fee policies for real estate holdings and transactions, increase the housing holding cost beyond the basic residential demand by levying property taxes, stipulate the period of limited sales, and levy the value-added tax on real estate transactions for the price increase exceeding the reasonable increase.

\subsection{Improve the external environment of the real estate industry}

The central government should establish a stable monetary environment, effectively control the circulation of money, maintain the relative stability of prices, and gradually squeeze out the real estate bubble. The financial sector should balance the support for the real estate industry and the real economy, implement differentiated housing loans, vigorously support loans that just need to limit multiple housing units, and strictly block the sources of funds for real estate speculation. The state should vigorously develop the real economy, encourage policies for people with the ability to start ventures or invest in entities, and reduce the competitiveness of the real economy by boosting administrative procedures and tax reductions. Renovate financial markets such as stocks, bonds, funds, etc., broaden investment channels, establish correct investment concepts, eliminate real estate bubbles, and prevent financial risks. To strengthen the supervision of social sensation, the media should take the responsibility of establishing the correct values of the people, and should not make false propaganda for private interests and become a drummer of high prices ${ }^{[5]}$.

\section{Conclusions}

In general, the rise in housing prices in China has affected the hearts of all parties in the society. The rising housing prices have made the people miserable and brought great harm to the people and the country. The excessive housing price mainly lies in the overburden of the functions of the real estate industry, the unsound governance system, the impact of monetary policy and the overheated investment of common people. Therefore, to build a long-term mechanism for the return of housing prices to rationality, we should first implement the positioning of the industry, and secondly, strengthen industry management from the aspects of industry development planning, land supply, construction process management, rent and sales, and taxation, and finally create a good external environment. Only the cooperation of the government, industry and society can make the house price return reasonably.

\section{Acknowledgements}

The research in this paper was supported by Special Scientific Research Plan of Shaanxi 
Provincial Department of Education: Research on the Warning of Xi'an City Real Estate Price Bubble Based on the Multivariable Lineal Regression Model under the New Normal of China's Economy (No.17JK1147)

\section{References}

[1] Chen Guoqiang. The long-term mechanism for the return of housing prices to rationality[J]. China Report, 2013(4): 82-83.

[2] Fan Kunbao. Talking about Establishing Long-term Mechanism of Real Estate[J]. China Real Estate, 2017(6):30-31.

[3] Wang Li. Research on the effect of real estate tax on housing prices [D]. Xi'an University of Technology, 2014.

[4] Huang Caiyun. On the Strategy of Promoting the Return of Rationality in China's Real Estate Market[J]. Modern Business, 2010, 2010(35):71-71.

[5] Huang Zhenqiang, Shen Honggen. Promoting the Reasonable Return of House Prices from Both Ends of Supply and Demand[J]. Times Financial, 2017(24): 291-292. 